\title{
Reality and fiction in Mohammad Rabie's novel, Otared
}

\section{A. A. Mokrushina}

St. Petersburg State University, 7-9, Universitetskaya nab., St. Petersburg, 199034, Russian Federation

For citation: Mokrushina A. A. Reality and fiction in Mohammad Rabie's novel, Otared. Vestnik SPbSU. Asian and African Studies, 2018, vol. 10, issue 1, pp. 68-74. https://doi.org/10.21638/11701/ spbu13.2018.106

The article provides an overview of the modern Egyptian novel of Mohammad Rabie. It is a dystopian piece that presents an alternative story of events that could have taken place after the Egyptian Revolution that took place in the country in January 2011. Rabie draws a picture of Egypt in 2025. The main protagonist of the novel, a policeman called Ahmad Otared, or as he is also called Mercury, witnesses terrible changes happening in the country that lead up to lawlessness, murders and robberies.

Keywords: Arabic literature, Egyptian literature, modern literature, novel, dystopia.

Despite the fact that we are witnessing a revival of interest to contemporary Arabic fiction among scholars of literary studies, the extent of published scholarship dealing with the Arabic prose and poetry which has appeared since the 1970s is still quite modest. As far as the younger generation of Arab writers is concerned, even experts in the field are little familiar with their work.

Young writers worldwide face a common challenge of reaching readers. Publishers, whether large or small, prefer to print works mostly of famous writers who have long since become classics. Very few publishers are willing to risk giving voice to unknown young authors, because it implies a low return rate as readers are reluctant to explore new names. This means publishers have to invest in promoting new titles to boost sales. Meanwhile, most are interested in making maximum profit at minimum cost.

Young unknown writers normally rely on foundations to get their books published in the hardcopy format. There are prizes awarded to young Arabic fiction writers in Arab countries. The Lebanon, Egypt and Kuwait are leading Arab nations in terms of the number of such publications.

Obviously, only a limited group of young authors are lucky to ever obtain sponsorship to have their works published. Most turn to the Internet as the cheapest and most accessible medium to get their message across. Young Arab authors are no exception: most of their works are available online.

Modern Arab writes focus on a wide variety of topics in their writings. They range from everyday struggles to political and philosophical themes, which are quite popular with readers in today's economic and political context. Young Egyptian writer Mohammad Rabie belongs to the fold of authors that delve into the political and philosophical domains.

Mohammad Rabie was born in 1978. He received an engineering degree from Cairo University [2]. Mohammad Rabie has written three novels, two of which were awarded

() Санкт-Петербургский государственный университет, 2018 
prestigious literary prizes or young writers and are critically acclaimed [3].

The author's latest novel is called عُارد (Mercury). However, in an English translation it came out as Otared, which is the last name of the main character. It is a dystopian piece that presents an alternative story of events that could have taken place after the Egyptian Revolution that took place in the country in January 2011. Rabie draws a picture of Egypt in 2025. The main protagonist of the novel, a policeman called Ahmad Otared, or, as he is also called, Mercury, witnesses terrible changes happening in the country that lead up to lawlessness, murders and robberies. Mercury is a sniper in the

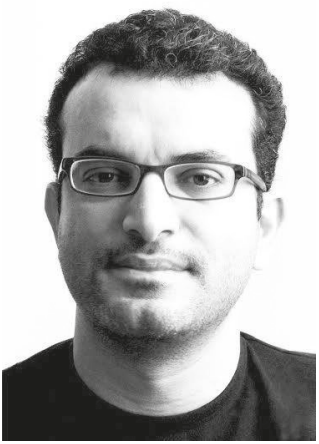

Fig. 1. Mohammad Rabie [1] popular resistance that fights forces wreaking chaos in the country. However, it soon becomes clear that the resistance serves its own interests: their members go on a regular killing spree of thousands of innocent people. The White bloodless revolution, a dream of many Egyptians, turns into a mass killing of the country's own people. The rebel leader tells his supporters that the time for a second people's revolution has come. This time their struggle should be directed against an occupying force. However, what plan does he suggest? Through the media the resistance plan to cause panic among

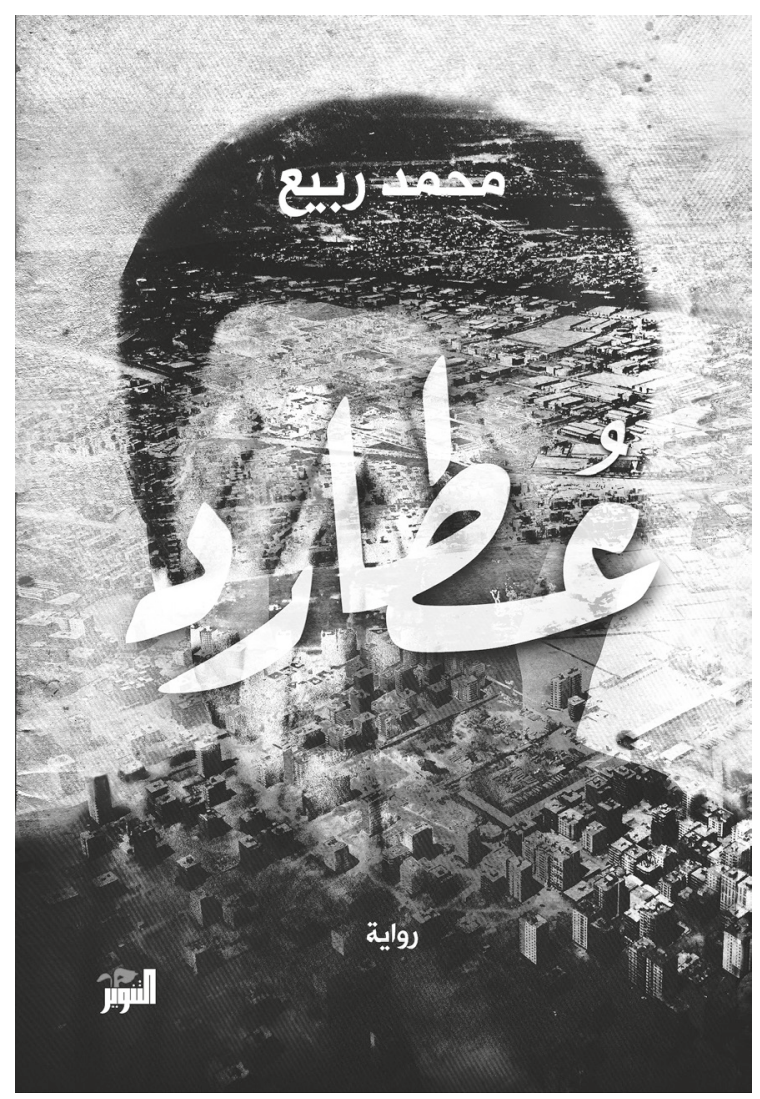

Fig. 2. Cover of the Novel "Otared" [4] 
the population so that ordinary people would believe that all evil comes from the occupiers. He makes the final conclusion saying: "People will understand that we are scoundrels, that we are killing them, but they will ultimately choose us, not the occupiers. Not because we are patriots, that we live in the same country as they do, and not because we speak the same language, but because we are going to kill them as long as the occupation goes on" [5, p. 65].

Rabie's novel may be shocking, but it clearly shows the young author's talent for creating a scary reality that grips the reader. The very first lines make us feel the pressure: "This line of blood puts me in mind of many things. It's traced on the wall, not quite vertically but leaning at a slight angle and at its apex bending sharply back to the ground. Small droplets hang down, running from the edge of the bend" [5, p.5]. This line of blood on the wall should be treated as a symbol whose meaning unfolds throughout the whole novel.

A short prologue engulfs the reader with the horror of the situation. On several pages the author describes a realistic but perhaps excessively graphic picture, in the manner more characteristic of contemporary American or European fiction, of an entire family being murdered. People are bewildered to see a normal middle-class man commit such an atrocious act. The only person who provides an answer to the question why the murderer has done what he has done is a tea boy: "He poured it calmly, picked up the little saucer that held the cup and handed it to me, and volunteered the following: "That's a cup of coffee with hope stirred in. Hope's important. That guy who murdered his family lost hope; that's why he killed them...'” [5, p. 14]. The motive of all hope lost rings throughout the whole book.

Structurally, Mohammad Rabie's novel is divided into five parts with a different number of chapters which have no names but are numbered. Some fragments of some chapters are separated from the rest of the text with asterisks. The unequal parts of the novel are dated 2023, 2025, 2011, 455 A. H., and then again 2011 and 2025. Thus, Rabie's narrative takes place in different times as he weaves events and characters together. Interestingly, only in 2023 and 2025 does the author let his main protagonist be the narrator.

Both in terms of content and composition, Otared is quite innovative for Arabic fiction. Employing description and attention to detail seem to be the only features that Rabie has taken from the traditional Arabic novel. Modern Arabic authors seek new themes and non-trivial ways of developing them. The 2011 Revolution in Egypt, which shook up not only the Middle East but the entire world, is viewed from an unusual angle in Rabie's novel. The author masterfully mixes fiction and real events that took place during that period. His characters live in Cairo and the familiar streets, districts and squares (Tahrir, Talat Harb, Bulak, Zamalik, Ataba, Corniche and the Opera House) become the setting for events in an alternative world. For instance, the main character says: "I was living in the district of Doqqi at the time. I was stationed in Qasr an-Nil in Jordan-city as were all other police officers who worked in East Cairo" [5, p.31]. At the same time, the text is full of familiar things such as mobile phones, drones, Sponge Bob masks, etc.

The author consciously simplifies the language to create the impression that this is an ordinary person's story, a story told by a former policeman, not a writer. On the other hand, Rabie uses mostly literary language rather than a dialect, including the dialogues, although some Egyptian words find their way into the text, e.g. كوبري (bridge) instead of

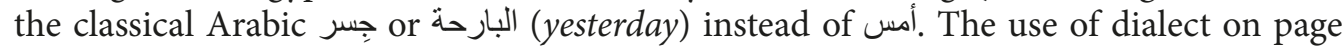
72 can be explained as an attempt to bring the Arabic reader back to a familiar reality when a character recites: "I am writing with my blood a new life of my homeland/ This is my blood, not spring". 
In this part of the novel, which the author dates $455 \mathrm{~A}$. H., he uses an unusual linguistic feature - a large number of diacritic symbols for short vowel sounds. The writer seems to stylize the fragment to fit the historical period in which the narrative unfolds.

Dialogues play an important part in Rabie's novel. Very few in number, they are extremely rich in meaning, relevant, and usually quite short. His phrases are quite short too, even abrupt, only to unfold later into details that fill the storyline. "Nothing, except chaos. I looked for some meaning in it, but it looks that those who built Cairo did look so far into the future... I have been part of what has been happening here for two years now and today I will put an end to it" [5, p. 21]. We can also point out the use of images and metaphors. However, the latter are not as plentiful as in traditional Arabic fiction. For example, the author calls "silent idols" ordinary residents of occupied Cairo, who are not able to offer a slightest resistance to the enemy. "Silent insanity gripped the Egyptians, forcing them to obediently accept everything that happened in the months that followed" [5, p.34]. Mohammad Rabie comes up with neologisms that could reflect living through the chaos of Cairo. So, the verb كربن appears and the derivative of it ككربن, that is, one who smokes a new drug كربون "carbon". "I asked Holy: "What do they call those who smoke carbon fiber? Carbon monkeys?" [5, p. 113].

Unusual for Arabic literature are numerous graphic details of life in a dilapidated city, in which chaos reigns, leading to a sharp drop in morality: houses of tolerance open everywhere in Cairo, everyone uses drugs, debauchery becomes the norm of life. In the text there are detailed descriptions of scenes of violence and sex, which further shape the image of society in which there are no basic concepts of law and morality. The protagonist's personality goes through a transformation: the moral principles, which he follows in the beginning, soon turn out to be distorted. At the beginning of the novel, Mercury executes orders guided by a patriotic feeling: the desire to liberate his homeland from the invaders and return the country to a peaceful life. But at the same time - he is a murderer, whose victims are civilians: "I just had to adapt to developments and await orders, all of them most specific: assassinate so-and-so who'd be passing down the Corniche; shoot any five officers of the occupation over the coming month" [5, p. 22]. However, soon Mercury realizes that he, like other members of the resistance, is being used to terrorize the country. He asks himself: "Maybe I was just an instrument to "take out" people?" [5, p. 97]. Meeting his antipode, who is known by the nickname of Holy, also makes Mercury look at what is happening around him from a different perspective. "I asked him: "Holy?" and he replied: "I've been given this nickname, because I did not kill anyone." I was amazed: "How is this possible?! We have been living under occupation for three years now. And all this time you never killed anyone?" [5, p.73]. The protagonist changes, and his ethical attitudes change - all this can be considered a sign of a quality novel. Such multidimensionality can hardly be considered traditional for classical Arabic literature.

Questions of conscience and morality are central to the novel. Through the main character, the author tries to find answers to them. In a conversation with his friend and companion, Mercury discusses the philosophical questions of existence, trying to understand what death is and whether there is something after it. It is in the conversation with Holy that the motive of hope, which was discussed in the prologue - hopes for life, comes up again. "People live in the hope of a better life" [5, p. 98]. There is a love line in the novel too, but the author does not really develop it.

Through his characters, Mohammad Rabie tries to comprehend what has happened in his country: the Revolution, the change of power and the subsequent events. One of 


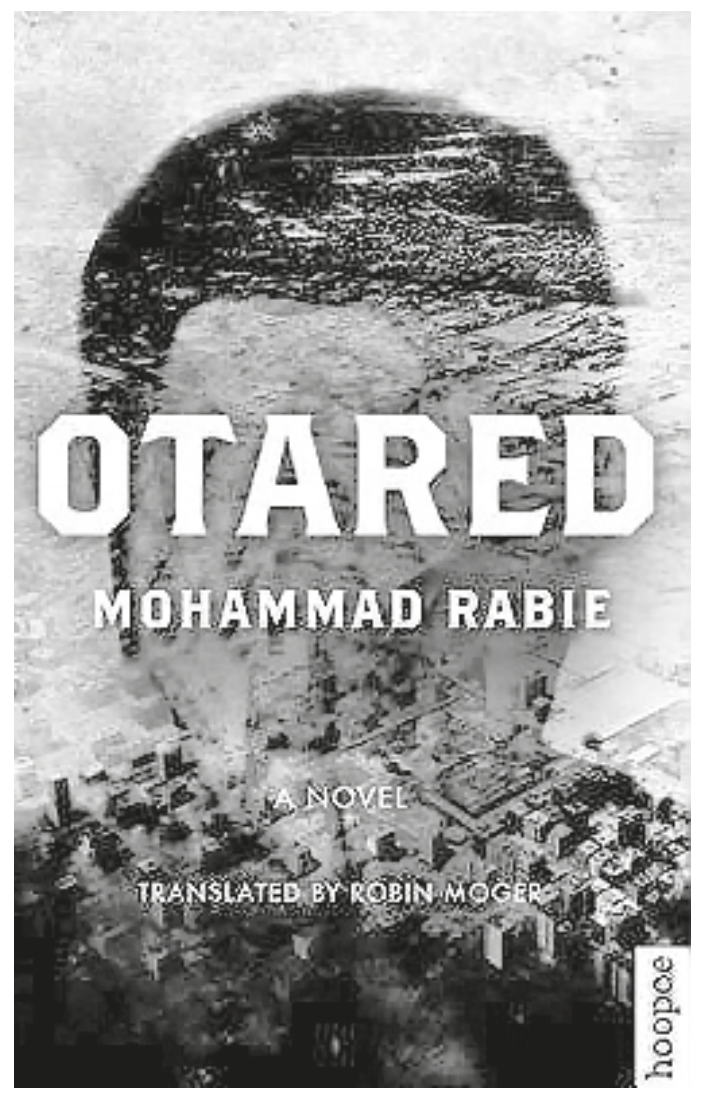

Fig. 3. Cover of the Novel "Otared" in the English version [6]

his characters says: "These are the consequences of what we ourselves have done, friends. If, then, in January, we had not opened fire, nothing would have happened. If we had just stood there, the army would never have overthrown Mubarak. But it happened. We learned how to shoot and learned how to get people to rebel" [5, p.71]. These words reflect the alarm of all Egyptians asking themselves questions after the January events: "what would have happened if ...?" And "what's next?"

Otared can be called innovative for a number of reasons: it has an original plot, an unusual form of textual composition, several intertwined story lines, imagery, motifs uncharacteristic of the traditional Arabic novel, and attention to minor characters. Today, young Arab authors are interested in genres that have long been the favorites of their European colleagues. In many respects, the dystopian novel, Otared, resembles similar works of Western writers - a fascinating plot, a short memorable name, and simple language. But at the same time, the author of the novel puts fictional events within the context of Egyptian life, allowing the Arab reader to feel part of the fictional world. Despite the fact that the work is intended for the general public, it is impossible to attribute this novel to the genre of entertaining literature. It is quite obvious that Mohammad Rabie tries to go beyond the obvious: he tries to warn against cruelty, which ordinary people become vic- 
tims of, and against terror and anarchy, to which this cruelty leads. On the other hand, the head of the military government of Egypt, who came to power after the first wave of the Revolution, sounds like Paul-Pierre Genevieve. Does the author want to say in this way that there is a foreign influence behind all that is happening in the country?

The work of Mohammad Rabie was first published in 2015 in Beirut, and owing to the fact that a year later the novel entered the short list of the prestigious Arab Booker prize, soon his translation into English appeared. It is interesting to note that the translator retained the name Otared, which is also the last name of the main character, without translation. Meanwhile the original novel's name in Arabic is Otared. In my opinion, and also taking into account several reviews of the novel, its name, Mercury, should be understood as a metaphor. Mercury as the planet closest to the Sun is the most vulnerable to its influence, it is closer to its destructive power.

Otared certainly reflects the influence of European and American literatures on the work of an Arab writer. However, it is impossible to say that the product resembles, let alone copies, foreign literature. The fact that the novel has come out in English can only testify to one thing: there is an increased interest to the Arabic contemporary literature in the West and an Egyptian take on the political events in the country generates additional interest.

\title{
References
}

1. https://www.madamasr.com/ar/2016/04/24/feature (accessed: 31.08.2017)

2. http://www.aljazeera.net/news/cultureandart/2016/ (accessed: 23.06.2017)

3. http://www.arabicfiction.org/ar/node/594 (accessed: 23.06.2017)

4. https://www.alaraby.co.uk/books/2015/1/25/ (accessed: 31.08.2017)

5. Muhammad Rabi. Utarid (Mercury). At-tanwir, 2015, 304 p.

6. https://www.goodreads.com/book/show/32610238-otared (accessed: 31.08.2017)

Received: 09.09.2017 Accepted: 06.12.2017

Author's information:

Mokrushina Amalia A. _- PhD; kodzik@inbox.ru

\section{Реальность и вымысел в романе Мухаммада Рабии «Меркурий»}

\author{
А. А. Мокрушина \\ Санкт-Петербургский государственный университет, \\ Российская Федерация, 199034, Санкт-Петербург, Университетская наб., 7-9
}

Для цитирования: Mokrushina A.A. Reality and fiction in Mohammad Rabie's novel, Otared // Вестник СПбГУ. Востоковедение и африканистика. 2018. Т. 10. Вып. 1. C.68-74. https://doi. org/10.21638/11701/spbu13.2018.106

Подробно рассматривается роман современного египетского прозаика Мухаммада Рабии «Меркурий». Произведение представляет собой яркий пример антиутопии. События, описанные в нем, альтернативным образом разворачиваются в Египте после январской революции 2011 г. Перед читателем предстает Египет в недалеком бу- 
дущем - 2025 г. Главный герой романа - полицейский по имени Ахмад Утарид или, как его называют, «Меркурий» - становится свидетелем страшных перемен в стране, приведших к беспределу, убийствам и грабежам. Автор статьи анализирует различные аспекты произведения М. Рабии - тематики, стиля, особенностей языка, обращая внимание и отмечая тенденции, свойственные современной литературе арабских стран. Произведение «Меркурий» можно назвать новаторским благодаря целому ряду моментов: это нестандартный сюжет, необычная форма построения текста, несколько переплетенных сюжетных линий, образность, несвойственные традиционному арабскому роману мотивы, внимание к второстепенным персонажам. Сегодня молодых арабских авторов привлекают жанры, уже давно полюбившиеся их европейским коллегам.

Ключевые слова: арабская литература, египетская литература, современная литература, роман, антиутопия.

Контактная информация:

Мокрушина Амалия Анатольевна - канд. филол. наук; kodzik@inbox.ru 